\title{
The seventh plenary of the intergovernmental platform for biodiversity and ecosystem services (IPBES-7): a global assessment and a reshaping of IPBES
}

\author{
Peter Bridgewater ${ }^{1,2} \cdot$ Adeline Loyau $^{3,4} \cdot$ Dirk S. Schmeller $^{3}$ (D)
}

Received: 22 May 2019 / Revised: 4 June 2019 / Accepted: 7 June 2019 / Published online: 17 June 2019

(c) Springer Nature B.V. 2019

\begin{abstract}
The Intergovernmental Science-Policy Platform for Biodiversity and Ecosystem Services (IPBES) held its 7th plenary session in Paris (France) during May 2019. The plenary marks the end of the first work programme and the release of the global assessment of biodiversity and ecosystem services. The important key messages from the global assessment are now more dire than those of the Millennium Ecosystem Assessment from 2005, and its precursor, the Global Biodiversity Assessment of 1995. The plenary also considered the results of the review of IPBES, the future rolling work programme until 2030, and a budgetary framework. Using the review to reframe IPBES' way of working, especially better policy delivery, will set it up for continued success.
\end{abstract}

Keywords Science-policy · Global assessment $\cdot$ Stakeholders $\cdot$ Nature conservation

The Intergovernmental Science-Policy Platform for Biodiversity and Ecosystem Services (IPBES) held its 7th plenary session (IPBES-7) in Paris (France) during May 2019. This IPBES plenary was calmer, more collegiate and more upbeat than the earlier plenaries we have reported on to readers of Biodiversity and Conservation (Schmeller and Bridgewater 2016; Schmeller et al. 2017; Bridgewater and Schmeller 2018). Globally, there is still growing interest in the work of IPBES reflected in the increasing number of states becoming IPBES members. Since the last plenary two new members joined IPBES, Jordan and

Communicated by David Hawksworth.

Dirk S. Schmeller

ds@die-schmellers.de

1 Institute for Applied Ecology, University of Canberra, 11 Kinnari Street, Bruce ACT 2617, Canberra, Australia

2 Centre for Museums and Heritage, Australian National University, Acton, ACT 0200, Australia

3 EcoLab, Université de Toulouse, UPS, INPT, CNRS, Toulouse, France

4 Department of Limnology of Stratified Lakes, Institute of Freshwater Ecology and Inland Fisheries, Neuglobsow, Germany 
the Bolivarian Republic of Venezuela, increasing the number of member states to 132 , with attendance at IPBES-7 from over 100.

IPBES-7 marked the end of the first work programme with the acceptance of the global assessment of biodiversity and ecosystem services and the future work programme. Two other items on the agenda were the review of IPBES (agreed at Plenary 5) and the development of a new work programme and budget. The summary for policymakers of the global assessments was approved after day and night sessions every day. This important document had a range of sobering messages, one of which has been dramatized by global media outlets as " 1 million species headed for extinction." The summary did include such a figure but in somewhat more nuanced terms. Other issues of interest to readers of Biodiversity and Conservation, and on which work, and manuscripts are encouraged, included:

- Deterioration of nature is not limited to lands and freshwaters-about $66 \%$ of the marine environment has been significantly altered by the activities of people, and a new governance framework is needed for the coasts and oceans.

- Crop, livestock and biofuel production now accounts for about three-quarters of the land and freshwater areas.

- Despite (or because) of that production level, land degradation has reduced the productivity of $23 \%$ of the global land surface.

- 100-300 million people are at increased risk of floods and hurricanes because of loss of coastal habitats and protection.

- Around one third of marine fish stocks are being harvested at unsustainable levels with the remaining two thirds largely fished to limits of sustainability.

- Inland fisheries are a significant component of production for protein needs across many parts of the world.

- Urban areas have more than doubled since 1992, but biodiversity in cities can be restored or encouraged through Blue-Green infrastructure, with concomitant improvements livability and human health.

- The rise of tele-coupling, i.e. distant areas of the world being increasingly connected as consumption, production, and governance decisions increasingly influence material, energy, and information flows across the world, generating aggregate economic gains while shifting economic and environmental costs. While generally positive again the assessment notes such cost and resource shifting can link to conflicts.

IPBES has undertaken 8 assessments, including pollinators and scenarios and pollination, four regional assessments, land degradation and at IPBES-7 the global assessment. All of these assessments build a picture around the scientific uncertainties remaining in our understanding of biodiversity and ecosystem services. Knowledge on such uncertainties help decisionmakers understand the state of knowledge and develop appropriate policies for the conservation, wise use and benefit sharing of biodiversity for human well-being.

The global assessment (GA) has not yet been formally edited. The approved summary for policy makers, however, is available at (https://www.ipbes.net/sites/default/files/downl oads/spm_unedited_advance_for_posting_htn.pdf) although even that will receive further editing. The global assessment is the first such assessment since the Millennium Ecosystem Assessment (MA 2005), and the first fully authorised and agreed by governments around the world. A little history seems appropriate here. By the mid of the 1990s, scientists, especially those involved in the work of the Convention on Biological Diversity (CBD) and biodiversity-related conventions, realized the need for scientific assessments of biodiversity to parallel assessments done by the Intergovernmental Panel on Climate Change (IPCC) for 
global climate. In 1995 the first such assessment, sponsored by the United Nations Environmental Programme (UNEP) and funded by the Global Environment Facility (GEF), the Global Biodiversity Assessment (Heywood 1995) was produced. However, the GBA had not been commissioned by governments and therefore was not recognized in the policy sphere, but was not only a very valuable assessment of biodiversity at that time, but included much background information still of value today. In 2000, the United Nations Secretary-General Kofi Annan then called for another such assessment, which became the Millennium Ecosystem Assessment. The MA had the objective to assess the consequences of ecosystem change and develop evidence-based recommendations to enhance the conservation and sustainable use of ecosystems and their contribution to human well-being. The work under the MA began in 2001 with the development of a conceptual framework and was published in 2005 (MA 2005). The MA was the first global assessment that demonstrated human impact on ecosystems, and showed the benefits, goods and services that ecosystems provide to human society. The MA called for significant policy changes in institutions and practices of biodiversity management at that time. The MA also made clear that major gaps in global and national monitoring systems resulted in the absence of welldocumented, comparable, time-series information for many ecosystems and that absence posed significant barriers in assessing condition and trends in ecosystem services. The MA also identified a lack of information species and underscored the limited information on the distributions of species-a situation now redressed to a degree by the establishment of the Global Biodiversity Information facility (GBIF; https://www.gbif.org/). Since 2005, efforts have increased to develop new monitoring systems and to improve knowledge (Pereira et al. 2010; Schmeller 2008; Schmeller et al. 2015), but important spatial, temporal and taxonomic gaps still remain (Mihoub et al. 2017; Wetzel et al. 2018).

Although some MEAs and UN Agencies were in the MA board it was also not officially authorised by governments, resulting in a more limited and lengthier uptake of the MA conclusions by decisionmakers. IPBES, however, as an intergovernmental platform has the capacity to provide a fully appropriate authorising environment. The 2019 GA is important as a new, updated authorized assessment of the state and trend of biodiversity and ecosystem services, to help determine appropriate policy choices for the future. In brief, the key messages of the global assessment are that nature promotes human well-being, but that it is deteriorating in unprecedented ways and at unprecedented rates. The GA restates that the current trajectories will not allow global achievement of nature conservation goals and the global Sustainable Development Goals. The GA calls for a transformative change across all of human society to allow those achievements in the necessary time frame of 20 years. The GA remains positive that nature can be conserved, restored and used sustainably with the suggested transformative change, and that it has significant benefits for human well-being.

A particular finding in the assessment was the link between biodiversity and mental health and well-being. The MA already pointed out a relationship between ecosystem degradation and degradation of the five components of human well-being (basic material needs for a good life, health, good social relations, security and freedom of choice and action), with mostly loss of capital asset and economic activity accounting for the link (MA 2005). However, it is becoming more and more evident that nature itself promotes human mental health, well-being and happiness, even after controlling for socio-economic factors (e.g. MacKerron and Mourato 2013; Twohig-Bennett and Jones 2018; Engemann et al. 2019). Once basic physical needs for food, shelter, health and safety have been met, increased wealth does not correlate with increased well-being or happiness (Carr 2013). This observation provides a solid ground for prioritising the necessary investments of industrialized, wealthy countries in the protection of biodiversity and the services it provides to society. 
At IPBES-7, the future work programme was also discussed by member states and accepted. The future work programme has a time horizon until 2030 but is designed as a rolling programme to cope with new challenges and needs. Priority deliverables agreed were: (1) thematic assessment of the interlinkages among biodiversity, water, food and health; (2) thematic assessment of the underlying causes of biodiversity loss and the determinants of transformative change and options for achieving the 2050 Vision for Biodiversity; and (3) methodological assessment of the impact and dependence of business on biodiversity and nature's contributions to people. These deliverables underpin six key objectives, "assessing knowledge", "building capacity", "strengthening the knowledge foundation", "supporting policy", "communicating and engaging", and "improving the effectiveness of the Platform". Because the GA specifically identifies, on a number of occasions, the links between biodiversity and climate change, a special deliverable within the next 12 months was agreed: A technical paper on the interlinkage between biodiversity and climate change-which will be a first joint effort between IPBES and IPCC.

Finally, while the GA has the potential to help shape the future of the world's biodiversity, the plenary also considered the results of a review established in 2017 on the whole IPBES programme. In 2017, the IPBES Secretariat conducted a limited internal review, the outputs from which were taken up by a 10-member review panel in 2018. Their terms of reference were to establish to what extent IPBES has been conceptualized; positioned; structured; and implemented, so as to achieve long-term impacts on biodiversity, human well-being and sustainable development.

The review noted several key achievements of IPBES, but pointed to five key areas that need attention: The transformative impact of IPBES depends on all its four functions (i.e. assessments, knowledge generation, policy tools, and capacity building) being significantly strengthened. IPBES needs to strengthen the policy aspects of its work if it is to fulfill its mandate as a science/knowledge-policy interface; maintain scientific independence while allowing for the co-design and co-production of assessments; develop a more strategic and collaborative approach to stakeholders; and, importantly, secure financial sustainability in the long-term, if it is to have on-going effectiveness. If those elements can be secured, the future of IPBES will also be secure, and its need is certainly undiminished.

Biodiversity and Conservation invites manuscripts on topics related to the GA with a global view on the transformative change evoked by IPBES through the GA. Such manuscripts could focus on how such a transformative change can be achieved, which elements need to be prioritized and within which time frame, to enable a nature conservation fit for purpose in the 21 st century that allows for co-existence of people and the rest of biodiversity.

\section{References}

Bridgewater P, Schmeller DS (2018) IPBES-6: the best plenary yet? Biodivers Conserv 27:2777-2782. https://doi.org/10.1007/s10531-018-1569-z

Carr A (2013) Positive psychology: the science of happiness and human strengths. Routledge, Abingdon

Engemann K, Pedersen CB, Arge L, Tsirogiannis C, Mortensen PB, Svenning J-C (2019) Residential green space in childhood is associated with lower risk of psychiatric disorders from adolescence into adulthood. Proc Natl Acad Sci 116:5188-5193

Heywood VH (ed) (1995) Global biodiversity assessment. Cambridge University Press, Cambridge

MacKerron G, Mourato S (2013) Happiness is greater in natural environments. Global Environ Change 23:992-1000 
Mihoub JB, Henle K, Titeux N, Brotons L, Brummitt N, Schmeller DS (2017) Setting temporal baselines for biodiversity: the limits of available monitoring data for capturing the full impact of anthropogenic pressures. Sci Rep 7:41591. https://doi.org/10.1038/srep41591

Millenium Ecosystem Assessment MA (2005) Ecosystems and human well-being: wetlands and water. World Resources Institute, Washington, DC

Pereira HM, Belnap J, Brummitt N, Collen B, Ding H, Gonzalez-Espinos M, Gregory RD, Honrado J, Jongman RH, Julliard R, McRae L, Proenca V, Rodrigues P, Opige M, Rodrigue JP, Schmeller DS, Cv Swaay, Vieira C (2010) Global biodiversity monitoring. Front Ecol Environ 8:459-460

Schmeller DS (2008) European species and habitat monitoring: where are we now? Biodivers Conserv 17:3321-3326

Schmeller DS, Bridgewater P (2016) The intergovernmental platform on biodiversity and ecosystem services (IPBES): progress and next steps. Biodivers Conserv 25:801-805. https://doi.org/10.1007/s1053 1-016-1095-9

Schmeller DS, Juillard R, Bellingham PJ, Böhm M, Brummitt N, Chiarucci A, Couvet D, Elmendorf S, Forsyth DM, Garcia-Moreno J, Gregory RD, Magnusson WE, Martin LJ, McGeoch MA, Mihoub J-B, Pereira HM, Proença V, Van Swaay C, Yahara T, Belnap J (2015) Towards a global terrestrial species monitoring program. J Nat Conserv 25:51-57

Schmeller DS, Niemelä J, Bridgewater P (2017) The intergovernmental science-policy platform on biodiversity and ecosystem services (IPBES): getting involved. Biodivers Conserv 26:2271-2275. https:// doi.org/10.1007/s10531-017-1361-5

Twohig-Bennett C, Jones A (2018) The health benefits of the great outdoors: a systematic review and metaanalysis of greenspace exposure and health outcomes. Environ Res 166:628-637

Wetzel FT, Bingham HC, Groom Q, Haase P, Kõljalg U, Kuhlmann M, Martin CS, Penev L, Robertson T, Saarenmaa H, Schmeller DS, Stoll S, Tonkin JD, Häuser CL (2018) Unlocking biodiversity data: prioritization and filling the gaps in biodiversity observation data in Europe. Biol Conserv 221:78-85. https://doi.org/10.1016/j.biocon.2017.12.024

Publisher's Note Springer Nature remains neutral with regard to jurisdictional claims in published maps and institutional affiliations. 